\title{
Comparative Life Cycle Assessment of Clinker Production with Conventional and Alternative Fuels Usage in Turkey
}

\author{
S. Çankaya and B. Pekey
}

\begin{abstract}
Recently, a considerable increase has been occurred in cement manufacturing, which is a highly intensive energy and resource consuming and carbon emission industry, in parallel with industrialization and urbanization. Turkey is the fourth largest cement producer in the world. Therefore, assessing the life cycle of clinker that is the main material of cement, defining the most important environmental impacts arising from clinker production and practicing the best available production techniques is vital for environmental sustainability. In this study, life cycle assessment of clinker production with conventional fuels was carried out in Turkey (which was named as scenario 1). Additionally, alternative scenarios using alternative fuels (refused derived fuel and dried sludge) were developed and comparative life cycle assessment (LCA) study was performed. As a result of the study, the most environmentally-friendly scenario was determined as Scenario 6 using dried sludge to produce one tone clinker.
\end{abstract}

Index Terms-Alternative fuel, clinker, environmental impact, life cycle assessment.

\section{INTRODUCTION}

Cement industry, which accounts for 5\% of global anthropogenic $\mathrm{CO}_{2}$ emissions, is potential anthropogenic source of air pollution [1], [2]. Turkey is the fourth largest cement producer in the world [3]. There are 54 integrated cement plants in Turkey. Eighteen plants are grinding and packing facilities. Clinker production capacity is 80 million tones and cement production capacity is 132 million tons by 2016 [4].

Clinker production is a significant $\mathrm{CO}_{2}$ emitter and the most energy-intensive part of the cement production process [5], [6]. About $60 \%$ of the $\mathrm{CO}_{2}$ emissions by cement plants are arising from the calcination process, whereas the rest is from the energy consumed during this process [7]. Overall, for one ton of Portland cement clinker $0.87 \mathrm{~kg}$ of $\mathrm{CO}_{2}$ is released into the atmosphere [8]. The important emissions in a cement kiln are nitrogen oxides $\left(\mathrm{NO}_{\mathrm{x}}\right)$, small quantities of dust, chlorides, fluorides, sulfur dioxide, carbon monoxide, and still smaller quantities of organic compounds and heavy metals in addition to $\mathrm{CO}_{2}$ [9]. The amount of $\mathrm{CO}_{2}$ emitted is significantly dependent on the manufacturing method and the type of fuel usage during production [7]. As significant amounts of GHGs (Greenhouse gases) emissions are resulted from the combustion of fossil fuels (petroleum coke, lignite, fuel oil, natural gas, diesel..etc), the use of alternative fuels has significantly increased recently [10], [11]. The most common

Manuscript received May 3, 2018; revised July 3, 2018.

The authors are with the Environmental Engineering Department, Kocaeli University, Kocaeli, Turkey (e-mail: simge.taner@kocaeli.edu.tr, bpekey@kocaeli.edu.tr). alternative fuels used globally in the cement industry sewage sludge, waste plastics, scrap tires, refused derived fuels, biomass wastes and textiles [11], [12]. Lots of studies using alternative fuels in order to produce clinker and discussing the environmental performance of them were conducted by researchers [11], [13]-[15].

In this study, we identified the environmental impacts of clinker production process in Turkey with a life cycle perspective. Current situation and five alternative scenarios (a total of 6 scenarios) were considered and the life cycle assessment was performed comparatively. As a result of the study, the most environmentally-friendly scenario was determined, and process contributions were discussed.

\section{MATERIAL AND METHOD}

\section{A. Goal, Scope and Functional Unit}

The goal of this LCA study is determine the environmental impacts of clinker production. The scope is defined as cradle to gate: raw material acquisition, raw material preparation, raw mill and clinker burning. Extraction and transportation of raw materials are included. Transportation of conventional fuels are included, but not extraction of them. In Turkey, most of coal was imported from Colombia (42.2\%) and Russia $(33.5 \%)$ in 2016 . Therefore, the distance of import coal was assumed that $8000 \mathrm{~km}$. The transportation of local coal was neglected because it was too small. Infrastructure and facilities are excluded because their impact is too small. The functional unit is one tone clinker.

\section{B. Life Cycle Inventory and Assumptions}

In this study, raw material and fuel amounts to produce clinker were obtained from the Ministry of Development of the Republic of Turkey, The State Planning Organization [16]. Average electricity consumptions in different stages of clinker production and fossil fuel usage rate $(\%)$ in Turkey were obtained from Salbaş (2016) [17]. Salbaş (2016) analyzed the 49 integrated cement plants in Turkey and identified the average electricity consumption for each production stage (raw material preparation, raw mill, kiln burning and cement grinding) and average $\mathrm{CO}_{2}$ emissions per ton clinker arising from cement production. According to this study, the $\mathrm{CO}_{2}$ emission is $849 \mathrm{~kg}$ per ton clinker [17].The heating values of refused derived fuel (RDF) for Turkey were obtained from SimaPro libraries (upper heating value: 13.27 $\mathrm{MJ} / \mathrm{kg}$; lower heating value: $11.74 \mathrm{MJ} / \mathrm{kg}$ ). The average kiln emissions in Turkey were obtained from the project of Directorate General of Environmental Management [18]. The fossil fuel consumption rate for cement industry in Turkey is presented in Fig. 1. 


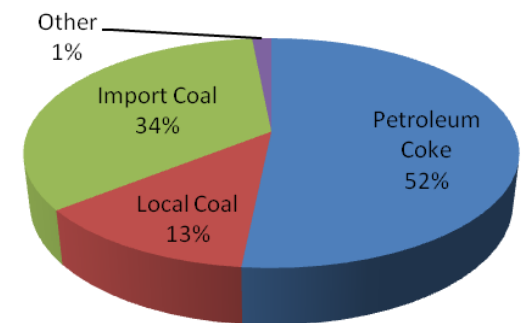

Fig. 1. Fossil fuel consumptions (\%) in 2014 (Adapted from [17]).

According to the fossil fuel consumptions in 2014 and the thermal requirements for the production of one ton clinker, we calculated the essential amount of fuel (petroleum coke and coal). The main inputs and outputs for clinker production with conventional fuels are presented in Table I. In this study, iron ore $(46 \% \mathrm{Fe})$ was also used as raw material to produce clinker in addition to limestone and marl.

TABLE I: LIFE CYCLE INVENTORY OF CLINKER PRODUCTION WITH

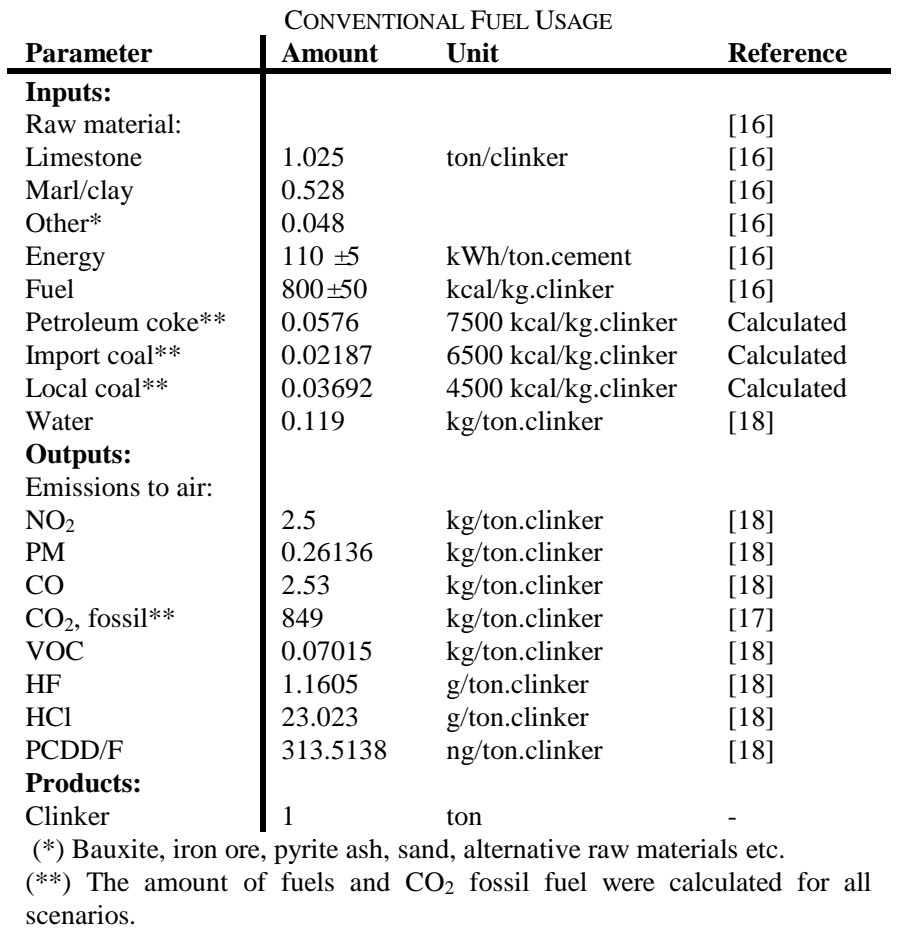

SimaPro 8.0.4 was used in order to assess the environmental impacts of clinker production for different scenarios. The inventory data for raw material acquisition (limestone and marl mining), electricity country mix were obtained from SimaPro libraries (Ecoinvent). The scenarios are as follows:

Scenario 1 (Current scenario): Thermal requirements to produce 1 ton clinker are supplied with $54 \%$ petro coke, $30 \%$ import coal, $12.3 \%$ local coal and $3.7 \%$ RDF (refused derived fuel).

Scenario 2 (Alternative scenario): Thermal requirement to produce 1 ton clinker are supplied with $10 \% \mathrm{RDF}, 50 \%$ petro coke, $20 \%$ import coal, $20 \%$ local coal.

Scenario 3 (Alternative scenario): Thermal requirement to produce 1 ton clinker are supplied with $20 \%$ RDF, $30 \%$ petro coke, $10 \%$ import coal, $40 \%$ local coal.

Scenario 4 (Alternative scenario): Thermal requirement to produce 1 ton clinker are supplied with $20 \%$ RDF, $30 \%$ petro coke, $10 \%$ import coal, $35 \%$ local coal, $5 \%$ natural gas.
Scenario 5 (Alternative scenario): Thermal requirement to produce 1 ton clinker are supplied with $30 \% \mathrm{RDF}, 30 \%$ petro coke, $10 \%$ import coal, $30 \%$ local coal.

Scenario 6 (Alternative scenario): Thermal requirement to produce 1 ton clinker are supplied with $30 \%$ SS (sewage sludge), $30 \%$ petro coke, $10 \%$ import coal, $30 \%$ local coal. It is assumed that the sewage sludge is thermally-dried before incineration in clinker kiln and its calorific value is 2500 $\mathrm{kcal} / \mathrm{kg}$.

\section{Life Cycle Impact Assessment}

Life cycle impact assessment was carried out with IMPACT 2002+ method, which is a combination of four methods: IMPACT 2002, Eco-indicator 99, CML and IPCC. The mid-point impact categories considered in IMPACT $2002+$ are carcinogens, non-carcinogens, respiratory inorganics, ionizing radiation, respiratory organics, aquatic ecotoxicity, terrestrial ecotoxicity, terrestrial acid/nutri, land occupation, aquatic acidification, aquatic eutrophication, global warming, non-renewable energy and mineral extraction. The end-point impacts are human health, ecosystem quality, climate change and resources.

\section{RESUlT AND DISCUSSIONS}

\section{A. Characterization and Process Contribution Analysis}

The characterization results of life cycle impact assessment (mid-point and end-point effects) for alternative scenarios are summarized in Table II. When the Scenario 1 (current situation) was taken into account, it was determined that imported lignite has high contribution to non-carcinogens, ionizing radiation, land occupation, aquatic eutrophication, and non-renewable energy. Kiln burning process is the highest contributor on global warming, aquatic acidification and terrestrial acid/nutri. Aquatic ecotoxicity, terrestrial ecotoxicity and mineral extraction are mostly affected from the raw mill production including raw material extraction, crushing and homogenization. According to the Table II, all impact categories decreased for alternative scenarios, except from aquatic eutrophication. Aquatic eutrophication impact increased for all scenarios (except from Scenario 6). Especially in Scenario 3, aquatic eutrophication has the highest impact (25\%). In this study, the main reason of the high aquatic eutrophication is usage of high amount of local coal $(40 \%)$, which has a low calorific value (about 4500 $\mathrm{kcal} / \mathrm{kg}$.clinker), in order to produce one tone clinker. When the inventory was examined, it has been determined that the highest contributor to aquatic eutrophication effect is phosphate.

The process contribution analysis of Scenario 6 was presented in Fig. 2. The main reason of reduction in aquatic eutrophication is raw sewage sludge for Scenario 6 as can be seen from the Fig. 2.

While the significant reduction has been determined in non-carcinogens; the important increment has been defined in respiratory organics (from $0.085 \mathrm{~kg} \mathrm{C}_{2} \mathrm{H}_{4}$ eq to $0.48 \mathrm{~kg}$ $\mathrm{C}_{2} \mathrm{H}_{4} \mathrm{eq}$ ) for Scenario 6 because of the sewage sludge usage. The most important contributor to reduction of non-carcinogens is dioxins in based on dried sludge usage. 
But, dried sludge usage can affect the respiratory organics adversely. The increment in respiratory organics arises from NMVOC (Non-methane volatile organic compounds) substantially. When the damage assessment was taken into account, we identified the $4 \%$ of reduction in human health impact category with using dried sludge for alternative fuel in clinker production.

\begin{tabular}{|c|c|c|c|c|c|c|c|}
\hline Impact category & Unit & scenario 6 & scenario 5 & scenario 4 & scenario 3 & scenario 2 & scenario 1 \\
\hline \multicolumn{8}{|l|}{ Mid-point impact: } \\
\hline Carcinogens & $\mathrm{kg} \mathrm{C} 2 \mathrm{H} 3 \mathrm{Cl}$ eq & $1.1 \mathrm{E}+00$ & $1.8 \mathrm{E}+00$ & $1.9 \mathrm{E}+00$ & $1.8 \mathrm{E}+00$ & $2.0 \mathrm{E}+00$ & $2.2 \mathrm{E}+00$ \\
\hline Non-carcinogens & $\mathrm{kg} \mathrm{C} 2 \mathrm{H} 3 \mathrm{Cl}$ eq & $-3.1 \mathrm{E}+00$ & $5.2 \mathrm{E}-01$ & $5.5 \mathrm{E}-01$ & $5.3 \mathrm{E}-01$ & $6.6 \mathrm{E}-01$ & $7.8 \mathrm{E}-01$ \\
\hline Respiratory inorg. & $\mathrm{kg}$ PM2.5 eq & $7.9 \mathrm{E}-01$ & $7.7 \mathrm{E}-01$ & $7.8 \mathrm{E}-01$ & 7.7E-01 & $7.9 \mathrm{E}-01$ & $8.0 \mathrm{E}-01$ \\
\hline Ionizing radiation & Bq C-14 eq & $2.1 \mathrm{E}+02$ & $2.8 \mathrm{E}+02$ & $3.0 \mathrm{E}+02$ & $2.8 \mathrm{E}+02$ & $4.1 \mathrm{E}+02$ & $4.9 \mathrm{E}+02$ \\
\hline Respiratory organics & $\mathrm{kg} \mathrm{C} 2 \mathrm{H} 4 \mathrm{eq}$ & $4.8 \mathrm{E}-01$ & $6.1 \mathrm{E}-02$ & $6.5 \mathrm{E}-02$ & $6.1 \mathrm{E}-02$ & 7.5E-02 & $8.5 \mathrm{E}-02$ \\
\hline Aquatic ecotoxicity & kg TEG water & $1.1 \mathrm{E}+04$ & $1.1 \mathrm{E}+04$ & $1.2 \mathrm{E}+04$ & $1.1 \mathrm{E}+04$ & $1.2 \mathrm{E}+04$ & $1.3 \mathrm{E}+04$ \\
\hline Terrestrial ecotox. & kg TEG soil & $3.0 \mathrm{E}+03$ & $3.3 \mathrm{E}+03$ & $3.3 \mathrm{E}+03$ & $3.3 \mathrm{E}+03$ & $3.7 \mathrm{E}+03$ & $4.2 \mathrm{E}+03$ \\
\hline Terrestrial acid/nut. & $\mathrm{kg} \mathrm{SO} 2 \mathrm{eq}$ & $1.5 \mathrm{E}+01$ & $1.6 \mathrm{E}+01$ & $1.6 \mathrm{E}+01$ & $1.6 \mathrm{E}+01$ & $1.6 \mathrm{E}+01$ & $1.6 \mathrm{E}+01$ \\
\hline Land occupation & m2org.arable & $9.4 \mathrm{E}-01$ & $1.6 \mathrm{E}+00$ & $1.6 \mathrm{E}+00$ & $1.6 \mathrm{E}+00$ & $2.4 \mathrm{E}+00$ & $3.2 \mathrm{E}+00$ \\
\hline Aquatic acid. & $\mathrm{kg} \mathrm{SO} 2 \mathrm{eq}$ & $2.2 \mathrm{E}+00$ & $2.2 \mathrm{E}+00$ & $2.3 \mathrm{E}+00$ & $2.2 \mathrm{E}+00$ & $2.3 \mathrm{E}+00$ & $2.4 \mathrm{E}+00$ \\
\hline Aquatic eutrop. & kg PO4 P-lim & $5.8 \mathrm{E}-02$ & $6.5 \mathrm{E}-02$ & 7.2E-02 & $7.8 \mathrm{E}-02$ & $6.2 \mathrm{E}-02$ & $6.2 \mathrm{E}-02$ \\
\hline Global warming & $\mathrm{kg} \mathrm{CO} 2 \mathrm{eq}$ & $8.9 \mathrm{E}+02$ & $9.1 \mathrm{E}+02$ & $9.0 \mathrm{E}+02$ & $9.1 \mathrm{E}+02$ & $9.2 \mathrm{E}+02$ & $9.5 \mathrm{E}+02$ \\
\hline Non-renewable en. & MJ primary & $1.9 \mathrm{E}+03$ & $1.9 \mathrm{E}+03$ & $2.2 \mathrm{E}+03$ & $2.1 \mathrm{E}+03$ & $2.2 \mathrm{E}+03$ & $2.4 \mathrm{E}+03$ \\
\hline Mineral extraction & MJ surplus & $2.0 \mathrm{E}+00$ & $2.6 \mathrm{E}+00$ & $2.7 \mathrm{E}+00$ & $2.6 \mathrm{E}+00$ & $3.0 \mathrm{E}+00$ & $3.5 \mathrm{E}+00$ \\
\hline \multicolumn{8}{|l|}{ End-point impact: } \\
\hline Human health & DALY & 0.000545 & 0.000548 & 0.000552 & 0.000548 & 0.000558 & 0.000567 \\
\hline Ecosystem quality & $\mathrm{PDF} * \mathrm{~m} 2 * \mathrm{yr}$ & 40.96042 & 44.65901 & 45.09949 & 44.70147 & 49.61359 & 54.13713 \\
\hline Climate change & $\mathrm{kg} \mathrm{CO} 2 \mathrm{eq}$ & 892.8601 & 905.2404 & 898.4188 & 911.5195 & 924.1752 & 945.2027 \\
\hline Resources & MJ primary & 1891.344 & 1893.867 & 2217.24 & 2073.99 & 2215.142 & 2422.118 \\
\hline
\end{tabular}

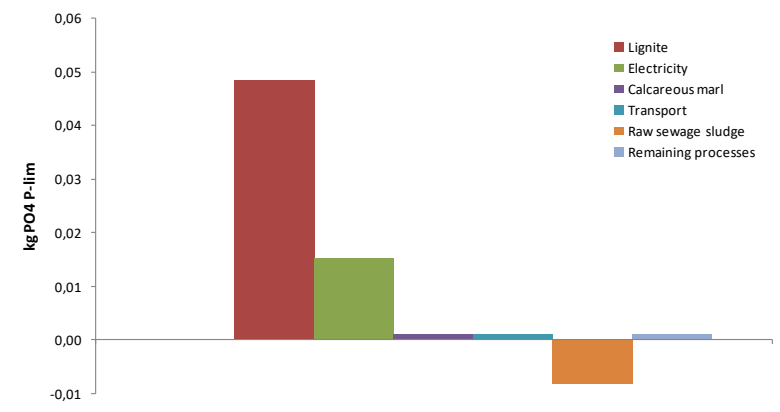

Fig. 2. The process contribution of aquatic eutrophication for Scenario 6.

Recently studies focusing on the determination of the potential human health risks of cement plants using sewage sludge as alternative fuels indicate that the option of using sewage sludge as alternative fuel represent an environmental improvement without additional health risk for the population [6], [19], [20]. Abuşoğlu et al. (2017) performed a comparative life cycle assessment (LCA) of a sewage sludge incineration for heat and power production with two scenarios: sewage sludge incineration plant based on a fluidized bed combustor (FBC) and a hypothetical cement kiln (CK) facility using sludge as a secondary fuel. The results of their study, in the human health category, the scores of the CK scenario preceded the scores of FBC for human health category [21]. Aranda-Uson et al. (2012) evaluated the environmental performance of clinker production using sewage sludge as alternative fuel with life cycle perspective for different scenarios. According to their study, three midpoint categories indicated an increment in the impacts with the addition of the sludge. It was clarified with the high content of heavy metals of the studied sewage sludge [22].

Considerable decrease has also seen in land occupation impact category. This impact category is impressed by transportation (road network, rail network...etc), mineral extraction site, arable, industrial area, dump site...etc. This result can be explained with the usage of different amount of import lignite, petroleum coke and natural gas (Fig. 3). Because the import lignite usage was decreased, land
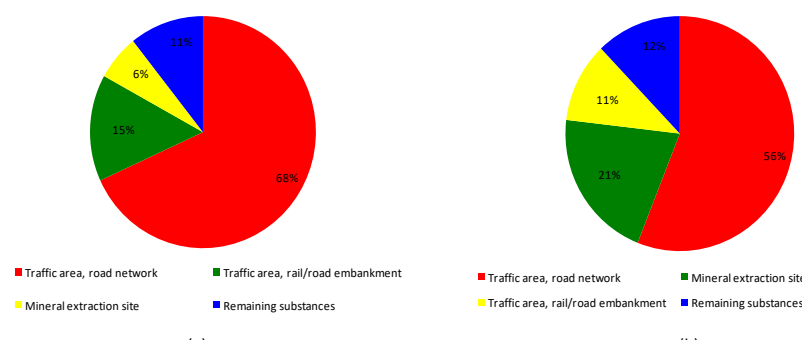

(b)

Fig. 3. Inventory of land occupation for Scenario 1 (a) and Scenario 6 (b).

\section{A. Normalization}

In addition to characterization results, normalization and weighting was also performed in order to determine the remarkable impacts arising from clinker production. 
According to the normalization results, climate change and human health are the most critical impacts arising from clinker production (Fig. 4). Approximately $50 \%$ of total environmental impact results from climate change; $41 \%$ from human health.

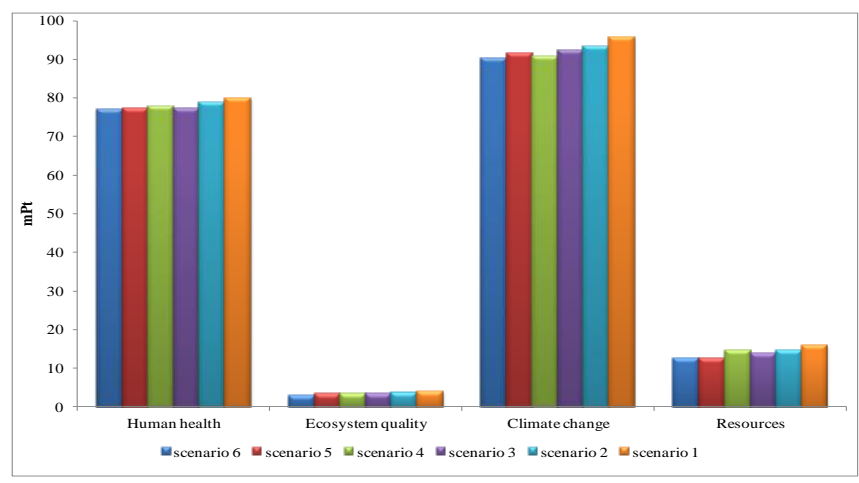

Fig. 4. Normalization results of different scenarios.

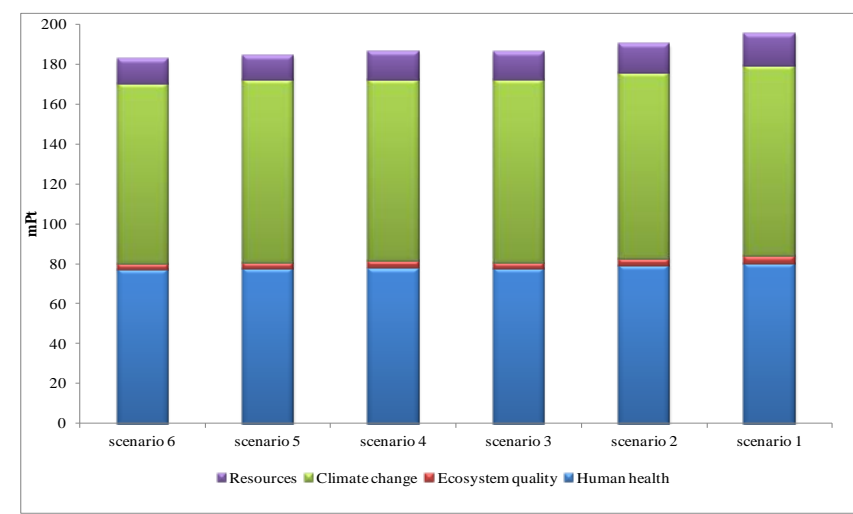

Fig. 5. The single score results of different scenarios.

Carbon dioxide is the main greenhouse gas arising from the cement [23] and the main contributor to climate change. Energy efficiency, the fuel mix which used to provide the required heat, and the amount of carbonate materials which used in clinker production are the main factors that determine $\mathrm{CO}_{2}$ emissions in cement production in addition to the clinker content of cement [5]. In this study we determined GWP is $945 \mathrm{~kg} \mathrm{CO}_{2}$ eq/ton.clinker for Scenario $1,924 \mathrm{~kg}$ $\mathrm{CO}_{2}$ eq/ton.clinker for scenario $2,912 \mathrm{~kg} \mathrm{CO}$ eq/ton.clinker for scenario 3, $898 \mathrm{~kg} \mathrm{CO}_{2}$ eq/ton.clinker for scenario 4, 905 $\mathrm{kg} \quad \mathrm{CO}_{2}$ eq/ton.clinker for scenario 5 and $892 \mathrm{~kg}$ $\mathrm{CO}_{2}$ eq/ton.clinker for scenario 6. Dried sludge usage reduced global warming impact significantly. Approximately $90 \%$ of $\mathrm{CO}_{2}$ emissions results from kiln burning and $4 \%$ from electricity according to the contribution analysis. These values are compatible with other results obtained in literature. Valderrama et al. (2013) carried out a life cycle assessment study of clinker production using urban sewage sludge as alternative fuel or raw material in order to evaluate the environmental impact of urban sewage sludge usage in clinker production. As a result of the study, $898 \mathrm{~g}$ and $906 \mathrm{~g} \mathrm{CO}_{2}$-eq per $\mathrm{kg}$ of clinker produced were obtained for the fuel substitution and without substitution, respectively (about $1 \%$ reduction) [6]. In our study, from $2 \%$ to $6 \%$ reduction occurred in accordance with the proportion of alternative fuel usage. When the human health impact category was analyzed, it was determined that the highest contributor to human health is respiratory inorganics. According to the result of damage assessment, the most important contributor is respiratory inorganics $(99 \%)$ which includes the $\mathrm{PM}_{2.5}(45 \%)$ and nitrogen dioxide $(41 \%)$.

When the scenarios were taken into account separately (Fig. $5)$, it is conspicuous that Scenario 6 is the most environmentally-friendly choice. As a result of the impact assessment, the single scores were identified $195 \mathrm{mPt}, 190$ $\mathrm{mPt}, 186 \mathrm{mPt}, 184 \mathrm{mPt}$, and $182 \mathrm{mPt}$ for scenario 1 , scenario 2 , scenario 3 and scenario 4 , scenario 5 and scenario 6; respectively.

\section{CONCLUSIONS}

In this study, we assessed the life cycle assessment of one ton clinker production for 6 scenarios in Turkey. Dried sewage sludge and refused derived fuel as an alternative fuel instead of conventional fuels for clinker production were evaluated. The results indicate that alternative fuel substitution has significant reductions on ecosystem quality (from $8 \%$ to $25 \%$ ), resources (from $8 \%$ to $22 \%$ ), climate change (from $2 \%$ to $6 \%$ ) and human health (from $2 \%$ to $4 \%$ ). It can be concluded that alternative fuel usage in clinker production not only reduces the global warming potential impact, but also reduces carcinogens, non-carcinogens, land occupation, ionize radiation, acidification, eutrophication, ecotoxicity, energy and mineral extraction. When the 6 scenarios were taken into consideration separately, the most environmentally-friendly option was determined as Scenario 6.

\section{REFERENCES}

[1] M. U. Hossain, C. S. Poona, Y. H. Dong, and D. Xuana, "Evaluation of environmental impact distribution methods for supplementary cementitious materials," Renewable Sustainable Energy Rev., vol. 82, pp. 597-608, 2018.

[2] D. A. Salas et al., "Environmental impacts, life cycle assessment and potential improvement measures for cement production: A literature review," J. Cleaner Prod., vol. 113, pp. 114-122, 2016.

[3] W. Shen et al., "Quantifying $\mathrm{CO}_{2}$ emissions from China's cement industry," Renewable Sustainable Energy Rev., vol. 50, pp. 1004-1012, 2015.

[4] Turkish Cement Manufacturers' Association. (2018). [Online]. Available:

http://www.tcma.org.tr/index.php?page=icerikgoster\&cntID=27

[5] M. E. Boesch and S. Hellweg, "Identifying improvement potentials in cement production with life cycle assessment," Environ. Sci. Technol., vol. 44, pp. 9143-9149, 2010.

[6] C. Valderrama et al., "Comparative LCA of sewage sludge valorisation as both fuel and raw material substitute in clinker production," $J$. Cleaner Prod., vol. 51, pp. 205-213, 2013.

[7] S. Ruan and C. Unluer, "Comparative life cycle assessment of reactive $\mathrm{MgO}$ and Portland cement production," J. Cleaner Prod., vol. 137, pp. 258-273, 2016.

[8] A. P. Gursel et al., "Life-cycle inventory analysis of concrete production: A critical review," Cem. Concr. Compos., vol. 51, pp. 38-48, 2014.

[9] S. Mishra and N. A. Siddiqui, "A review on environmental and health impacts of cement manufacturing emissions," IJGAES, vol. 2, no. 3, 2014.

[10] F. N. Stafford et al., "Life cycle assessment of the production of cement: A Brazilian case study," J. Cleaner Prod., vol. 137, pp. 1293-129, 2016.

[11] M. U. Hossain et al., "Comparative LCA on using waste materials in the cement industry: A Hong Kong case study," Resour. Conserv. Recycl., vol. 120, pp. 199-208, 2017.

[12] F. N. Stafford et al., "Life cycle assessment of the production of Portland cement: A Southern Europe case study," J. Cleaner Prod., vol. 126, pp. 159-165, 2016. 
[13] B. Reza et al., "Environmental and economic aspects of production and utilization of RDF as alternative fuel in cement plants: A case study of Metro Vancouver waste management," Resour. Conserv. Recyc., vol. 81, pp. 105-114, 2013.

[14] L. Zhang and W. E. Mabee, "Comparative study on the life-cycle greenhouse gas emissions of the utilization of potential low carbon fuels for the cement industry," J. Clean. Prod., vol. 122, pp. 102-112, 2016.

[15] K. Gabel and A. M. Tillman, "Simulating operational alternatives for future cement production," J. Clean. Prod., vol. 13, pp. 1246-1257, 2005.

[16] Ministry of Development of the Republic of Turkey. (2018). The State Planning Organization, Ninth Development Plant. [Online]. Available: www3.kalkinma.gov.tr/DocObjects/Download/3869/oik703-c2.pdf

[17] N. Salbaş, "Sustainable cement sector index," Postgraduate thesis, Başkent University Intstitute of Science and Engineering, 2016.

[18] Ministry of Environment and Urbanization, Directorate General of Environmental Management. (2018). [Online]. Available: http://cygm.csb.gov.tr/hava-yonetimi-dairesi-baskanligi-i-452

[19] J. Rovira et al., "Use of sewage sludge as secondary fuel in a cement plant: human health risks," Environ. Int., vol. 37, pp. 105-111, 2011.

[20] M. Schuhmacher, M. Nadal, and J. L. Domingo, "Environmental monitoring of PCDD/Fs and metals in the vicinity of a cement plant after using sewage sludge as a secondary fuel," Chemosphere, vol. 74, pp. 1502-1508, 2009.

[21] A. Abuşoğlu et al., "Life cycle assessment (LCA) of digested sewage sludge incineration for heat and power production," J. CleanerProd., vol. 142, pp. 1684-1692, 2017.

[22] A. Aranda-Usón et al., "Characterisation and environmental analysis of sewage sludge as secondar fuel for cement manufacturing," Chem. Eng. Trans., vol. 29, pp. 457-462, 2012.

[23] S. Vos et al., "LCA of thermal treatment of waste streams in cement clinker kilns in Belgium," Comparison to Alternative Treatment Options, 2007.

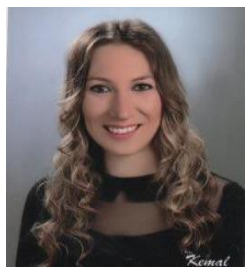

Simge Çankaya received the M.Sci. degree from the Kocaeli University, Kocaeli, Turkey in 2012, with the environmental engineering. She is currently Ph.D. Candidate at Kocaeli University, Department of Environmental Engineering.

She has been working as a research assistant at the same department from 2010.

Her research interests have included the life cycle assessment, indoor and outdoor air pollution, particulate matter pollution. 